\title{
The responsibility to protect: paradigm or pastiche?
}

HURST HANNUM ${ }^{1}$

\author{
Fletcher School of Law and Diplomacy, Tufts University (USA)
}

\begin{abstract}
A $t$ its core, the notion that every individual state and the "international community" have A a responsibility to ensure that individuals are protected from gross crimes and lifethreatening situations wherever they live is a moral, even noble, goal. It reflects the increasing humanisation of international relations and is consistent with the ever-increasing commitment by states to human rights.
\end{abstract}

Unfortunately, the campaign that has evolved in recent years for recognition of a "responsibility to protect" ("R2P" or "RtoP") as an international norm or even a guiding principle for international relations suffers from serious problems. The vagueness, hyperbole and neo-colonial undertones of R2P may have the unwelcome consequence of making it more, not less, difficult to reach consensus on criteria for humanitarian intervention in the future. In addition, as the responsibility to protect continues to evolve within the labyrinthine corridors of the United Nations, what little potential it might have had as a catalyst for action is diminishing rather than increasing. Finally, it may make it even more difficult to promote and protect human rights, properly understood, if a clear distinction is not maintained between the moral-political aspirations of the responsibility to protect and the legally binding norms of international human rights law.

This brief commentary challenges both the initial concept of the responsibility to protect and its subsequent development. Despite the fact that the concept now has its own scholarly journal ${ }^{2}$ and a New York-based think tank, ${ }^{3}$ it is submitted that the responsibility to protect has become more a slogan than a programme, and its continued promotion is

1 Professor of International Law, Fletcher School of Law and Diplomacy, Tufts University (USA). I have no idea whether Tom Hadden, to whom this volume is dedicated, would endorse the ideas or approach of this article, but I am confident that he would analyse "R2P" with the same blend of legal rigour and political pragmatism that has always characterised his work. Tom might never describe a glass as "half full" or "half empty"; instead, he would simply tell us how much water was in the glass and proceed to offer innovative ideas about how to fill it or empty it, depending on one's goal.

2 The journal, Global Responsibility to Protect, appeared in 2009 and is published by Martinus Nijhoff.

3 The Global Centre for the Responsibility to Protect was founded in February 2008 and is housed at the Ralph Bunche Institute for International Studies at the City University of New York Graduate Center. Initial funding for the centre was provided by the governments of Australia, Belgium, Canada, France, The Netherlands, Norway, Rwanda, and the United Kingdom; the John D and Catherine T MacArthur Foundation; the Open Society Institute, and Scott Lawlor. Its International Advisory Board is co-chaired by former ICISS co-chairs Gareth Evans and Mohamed Sahnoun. See http://globalr2p.org/about.html. 
likely to do more harm than good. The primary criticisms of the concept refer to its vagueness; the exaggerated claims of its sponsors; its breadth; and, ironically, its limitations. The legitimacy of the responsibility to protect is further undermined by its birth in the context of the NATO bombing of Kosovo and Serbia, which continues to colour the concept's interpretation by both supporters and detractors.

\section{Inherent vagueness}

The genesis of the responsibility to protect lies in the 2001 report of the International Commission on Intervention and State Sovereignty (ICISS), which was created a year earlier by the Canadian government to consider how the international community "should respond in the face of massive violations of human rights and humanitarian law". "The commission argued that substituting the concept of the "responsibility to protect" for that of "humanitarian intervention" better reflected the desired focus on victims, rather than the intervener, and was more likely to be acceptable to states. While the report does contain useful guidelines and discussion of the criteria for the use of force when widespread atrocities occur (under the rubric "the responsibility to react"), it also advocates recognising a responsibility to prevent and a responsibility to rebuild; the last two are discussed in the next section.

Although the ICISS Report has been informally abandoned as the responsibility to protect attempts to enter the international legal and diplomatic mainstream, it is worth recalling its main conclusions regarding what the appropriate response should be to mass killings. ${ }^{5}$ On the question of the threshold criteria that would justify a decision to intervene with military force, the report is relatively clear: intervention is permissible to prevent actual or imminent large-scale loss of life or ethnic cleansing. ${ }^{6}$ It adds that any intervention should meet conditions of right intention ("overthrow of regimes is not, as such, a legitimate objective"), ${ }^{7}$ last resort, proportional means, and reasonable prospects of success. ${ }^{8}$ More problematic is the recommendation that there should be "incrementalism and gradualism in the use of force", 9 in light of the actual or apprehended large-scale loss of life that is required to trigger a legitimate intervention.

On the essential question of who should have the authority to authorise the use of force, the commission fudges just a bit. While it observes that there is "absolutely no doubt that there is no better or more appropriate body than the [UN] Security Council", 10 it goes on to warn that, if the council fails to act, "it is unrealistic to expect that concerned states will rule out other means and forms of action to meet the gravity and urgency of these situations". 11

4 International Commission on Intervention and State Sovereignty, The Responsibility to Protect (Ottawa: International Development Research Centre 2001), App. B at p. 81 (hereinafter ICISS Report). The commission was co-chaired by Gareth Evans (former Foreign Minister of Australia) and Mohammed Sahnoun of Algeria (former Special Advisor to the UN Secretary General and Special Representative for Somalia and the Great Lakes); the other members were Gisèle Côté-Harper, Lee Hamilton, Michael Ignatieff, Vladimir Lukin, Klaus Naumann, Corral Ramaphosa, Fidel Ramos, Cornelio Sommaruga, Eduardo Stein and Ramesh Thakur. The full text of the report and related documents are available at www.iciss.ca/menu en.asp.

5 The ICISS Report includes a convenient synopsis of its main principles at pp. xi-xiii.

$6 \quad$ ICISS Report, para. 4.19

7 Ibid. para. 4.33 .

8 Ibid. paras 4.32-43.

9 Ibid. p. xiii.

10 Ibid. para. 6.14.

11 Ibid. para. 6.39. 
Nonetheless, the commission's basic argument that "the debate about intervention for human protection purposes should focus not on 'the right to intervene' but on 'the responsibility to protect" 12 leaves many questions unanswered. Is a "responsibility" to protect equivalent to an "obligation" to protect? One assumes not, or Canada and likeminded countries would have forces in Darfur and elsewhere, irrespective of the lack of action by the Security Council. References to the "international community" or the "broader community of states" scattered throughout the report are of little help in identifying just who might have what responsibility.

Unfortunately, international consideration of the commission's recommendations was sidetracked in the aftermath of the attacks on the United States on 11 September 2001, and it was not until 2005 that the UN took formal note and gave the first inter-governmental support to this new concept. That support, weak though it was, has reinvigorated those who wish to make the responsibility to protect a touchstone for international relations based on the needs of individuals.

\section{Hyperbole}

I have generally referred to the responsibility to protect as a "concept", which is a rather imprecise term, but many of its proponents are much more enthusiastic. Citing the 2005 World Summit document and the corresponding UN General Assembly resolution, they gushingly state that states have "unanimously endorsed"13 or "accepted"14 the responsibility to protect or, as in the brochure for a conference on the responsibility to protect held at Cardozo Law School in March 2008, that "world leaders made an historic decision to embrace" the concept.

Unfortunately, the reality doesn't match the claims, as an objective reading of the World Summit document makes clear. Two paragraphs of the World Summit Outcome Document refer to the responsibility to protect, and it may be useful to quote them in full:

138 Each individual State has the responsibility to protect its populations from genocide, war crimes, ethnic cleansing and crimes against humanity. This responsibility entails the prevention of such crimes, including their incitement, through appropriate and necessary means. We accept that responsibility and will act in accordance with it. The international community should, as appropriate, encourage and help States to exercise this responsibility and support the United Nations in establishing an early warning capability.

139 The international community, through the United Nations, also has the responsibility to use appropriate diplomatic, humanitarian and other peaceful means, in accordance with Chapters VI and VIII of the Charter, to help to protect populations from genocide, war crimes, ethnic cleansing and crimes against humanity. In this context, we are prepared to take collective action, in a timely and decisive manner, through the Security Council, in accordance with the Charter, including Chapter VII, on a case-by-case basis and in cooperation with relevant regional organizations as appropriate, should peaceful means be inadequate and national authorities are manifestly failing to protect their populations from genocide, war crimes, ethnic cleansing and crimes against humanity. We stress the need for the General Assembly to

12 ICISS Report, para. 2.29.

13 R2P Coalition, home page, http://r2pcoalition.org/component/option,com_frontpage/Itemid,1/.

14 Global Centre for the Responsibility to Protect, home page, http://globalr2p.org/. 
continue consideration of the responsibility to protect populations from genocide, war crimes, ethnic cleansing and crimes against humanity and its implications, bearing in mind the principles of the Charter and international law. We also intend to commit ourselves, as necessary and appropriate, to helping States build capacity to protect their populations from genocide, war crimes, ethnic cleansing and crimes against humanity and to assisting those which are under stress before crises and conflicts break out. ${ }^{15}$

Paragraph 138 of the Outcome Document affirms that each individual state has the responsibility to protect its population from international crimes. While welcome, this is hardly much of a political or moral advance, since these crimes are prohibited under customary international law; states are already obliged to prevent and/or punish them. Wellestablished international human rights norms impose a much broader range of obligations on states, and they have been accepted for decades. Thus, paragraph 138 merely reiterates a minimum state obligation rather than breaking new ground.

Paragraph 139 refers to the mythical "international community" as having a responsibility to help protect populations and then does little more than reaffirm relevant provisions of the UN Charter. Its reference to using the Security Council "on a case-by-case basis ... should peaceful means be inadequate ..." to combat these crimes adds some clarification to the council's powers, but such powers have been widely accepted at least since the council authorised the use of force in Somalia in 1992. Securing the political will to use those powers, of course, is quite another matter.

The Group of 77 has formally rejected the concept of unilateral humanitarian intervention at least twice in the past decade in ministerial declarations, and their agreement to the minimalist references in the Summit Outcome Document hardly evidences a major shift in position. ${ }^{16}$ While the impression is given by responsibility to protect advocates that UN member states recognised the significance of its inclusion in the Summit Outcome, Kieran Prendergast, former UN Under-Secretary General for Political Affairs, referred tongue in cheek to that inclusion as resulting from the "brilliant humanitarian intervention" by the then Canadian ambassador to the United Nations, Allan Rock, who managed "to slip in a paragraph" on the responsibility to protect into the Summit Outcome. ${ }^{17}$

There is nothing wrong with holding governments accountable for their own hypocrisy; this is a technique that is employed by human rights advocates every day, when they appeal to states simply to live up to their obligations under treaties that they have ratified. However, it is disingenuous, to say the least, to refer to the responsibility to protect as a concept around which there is a consensus or to suggest, in the words of the Global Centre for the Responsibility to Protect, that all that is now needed is ". . . to ensure that this R2P doctrine is understood and put into practice by governments and at the United Nations . . . [and] to promote and catalyze international action". 18

152005 World Summit Outcome, UN GA Res. A/60/1 (2005), paras 138, 139.

16 See Ministerial Declaration, 23rd Annual Meeting of the Ministers for Foreign Affairs of the Group of 77, 24 September 1999, para. 69, available at www.g77.org/doc/Decl1999.html; Declaration of the Group of 77 South Summit, 10-14 April 2000, UN Doc. A/55/74 (2000), para. 54.

17 Interview with Kieran Prendergast, Frontline, 29 June 2007, quoted at www.pbs.org/wgbh/pages/frontline /darfur/interviews/prendergast.html.

18 http://globalr2p.org/index.html. Among the centre's goals is "to advance and consolidate the World Summit consensus on R2P”. 


\section{Breadth of the concept}

While the range of situations in which the responsibility to protect would be activated has been narrowed, the range of international actions to be undertaken is vast. In 2001, the ICISS Report set forth a responsibility to prevent as well as to react to large-scale loss of life, and prevention is underscored in the UN Secretary General's 2009 report on the responsibility to protect. ${ }^{19}$ Unfortunately, neither document offers anything new or suggests in which respects preventing truly horrific crimes is any different from preventing less serious crimes, violence, or human rights violations from occurring. In 2009, it is simply not enough to fall back on familiar themes such as early warning, attention to the root causes of conflict, or the ubiquitous "toolbox" of conflict resolution/management techniques - or to conclude with the nostrum that "conflict prevention must be integrated into policies, planning and programmes at the national, regional and international levels". 20

More alarmingly, the ICISS report also propounded a "responsibility to rebuild", which appears to have been accepted by no one and which has rarely appeared in any subsequent discussion of the responsibility to protect in a UN document. Is a commitment "to helping to build a durable peace, and promoting good governance and sustainable development" 21 truly necessary to stop mass killings? Are even those states that are supportive of the responsibility to protect willing to accept such an open-ended commitment? Will the call for a commitment to rebuild a state make it more or less likely that a state will intervene even temporarily to prevent mass deaths? Promoting good governance and sustainable development are worthy goals, but they broaden the concept of the responsibility to protect beyond recognition.

Linking the responsibility to protect to international crimes is equally problematic, particularly if that linkage implies a responsibility to prosecute the criminals. Prosecuting those accused of genocide or other mass atrocity crimes is important, but what is its connection to an external responsibility to protect civilians? The world was (rightly) happy to forgive the crime against humanity called apartheid, after South Africa decided that a non-prosecutorial response to that crime was preferable, and such deference to local or national judgment is appropriate.

It is too early to judge the effectiveness of the International Criminal Court (ICC), but there is little evidence to suggest that international criminal prosecution deters those who believe that it is unlikely that they will be caught, if that is the justification for including the prosecution of criminals within the scope of the responsibility to protect. The existence of the International Criminal Tribunal for the former Yugoslavia certainly did not prevent the massacre at Srebrenica in 1995 or deter Milosevic four years later from expelling hundreds of thousands of persons from Kosovo after the NATO bombing began - nor has the ICC brought peace to Sudan.

The ICC may be a worthy initiative in and of itself, but its real impact is likely to be minimal for decades. There is no reason to link its success or failure to the urgent need to protect civilians at risk, which should be the primary motivation behind the responsibility to protect. In any event, providing both reconciliation and retribution is likely to be well beyond the capacity of outside intervenors, no matter how well intentioned.

Well-meaning NGOs that focus on various crisis situations have broadened the responsibility to protect even further. For example, the Elders, a group of senior former

19 See n. 30 below.

20 ICISS Report, para. 3.39.

21 Ibid. para. 5.1. 
leaders established by Nelson Mandela, Graca Machel and Desmond Tutu, cited the responsibility to protect in a 2007 report on Darfur as requiring governments and individuals to address "the concerns of the ordinary people of Sudan and to fund efforts to improve access to education for children in the displaced camps and to give them an alternative to the gangs". ${ }^{22}$ The International Crisis Group identified the situation in Zimbabwe in 2005-08 as

a clear instance of ... [the international community's] Responsibility to Protect ... not only to assist the victims of Murambatsvina [a 2005 campaign to clear slums], but more broadly, to encourage active efforts . . . to cope with the political, economic and social problems in Zimbabwe. ${ }^{23}$

Put simply, any concept that includes preventing and halting genocide; rebuilding societies and creating sustainable development; prosecuting international criminals; coping with political, economic and social problems; and improving access to education for children is simply too all-encompassing to be meaningful. It remains to be seen whether this broad popular conception of the responsibility to protect will survive formal UN attempts to restrict its applicability to certain international crimes, but the appeal of the slogan may make it difficult to maintain the narrow definition that seems to be a sine qua non for continued UN approval.

\section{The shrinking scope of the concept}

While its advocates initially advanced a broad understanding of the responsibility to protect, the 2005 World Summit Outcome narrowed its scope appreciably by referring only to "genocide, war crimes, ethnic cleansing and crimes against humanity", presumably when these crimes are widespread, as opposed to sporadic. This minimalisation of the "trigger" for the responsibility to protect to four internationally recognised crimes is a significant step backwards; were the original concept retained, the concept would be both clearer and broader - and we would not need to spend time arguing about whether the Burmese government's failure to allow international assistance after the 2008 cyclone constituted a "crime against humanity".24

The contemporary UN definition of the responsibility to protect also requires authorisation from the Security Council if force is contemplated, leaving no room, legally or politically, for action by other states in the region acting jointly or separately. Such a reaffirmation of Article 2(4)'s prohibition against the use of force is no doubt welcomed by most countries, but also makes clear that neither the 1999 intervention in

22 The Elders, Bringing Help, Forging Peace: The Elders' mission to Sudan (The Elders Inc. 2007), p. 24, http://dl.groovygecko.net/anon.groovy/clients/akqa/projectamber/press/sudan/The_Elders_Mission_to_ Sudan.pdf. Tutu is a "patron" of the Global Centre for R2P, as is Mary Robinson, another member of the Elders.

23 International Crisis Group, www.crisisgroup.org/home/index.cfm?id=4521\&l=1\#reporting. Indeed, the Crisis Group's website now has a separate section devoted to R2P. See www.crisisgroup.org/home /index.cfm?id $=4521 \& \mathrm{l}=1$ \#situations. Gareth Evans is also president and CEO of the International Crisis Group.

24 Cf. G Evans, "Facing up to our responsibilities", The Guardian, 12 May 2008. 
Kosovo nor any potential intervention by outside actors in Sudan is legal - absent the council's authorisation. ${ }^{25}$

This narrowing appears to be the price of continued support, often tacit or grudging, from many developing countries. As Prendergast observed, two years after the adoption of the Summit Outcome, the responsibility to protect remains

a very neuralgic concept for the Third World ... [t] he truth is that when it comes to it, the great majority of the member states don't mean it. They attach much more weight and importance to maintaining the principle of national sovereignty and noninterference than they do to any responsibility to protect. I'm sorry to say it. I mean, I don't like it, but nevertheless, it is the truth. ${ }^{26}$

A similar observation was recently offered by the UN High Commissioner for Refugees: "Most of the developing world sees the R2P as a conceptual camouflage designed to enable the Western states to pursue their interests by interfering in less prosperous countries."27

Yet one of the strongest elements in the ICISS Report was its willingness to address the essential political and legal criteria for armed intervention in unusually understandable and non-technical terms. The two "just causes" that could trigger intervention were 1) "largescale loss of life, actual or apprehended, with genocidal intent or not" or 2) "large-scale 'ethnic cleansing', actual or apprehended". 28 Thus, the focus was correctly placed on the plight of the victim, and the commission's "responsibility to react" would have been engaged whenever the state in which the loss of life was occurring either caused the loss of life or neglected or was unable to act to prevent or stop it.

One should not pretend that gaining acceptance of criteria that would legitimise armed intervention will be easy, but that acceptance will surely not occur if responsibility to protect proponents continue to ignore or obfuscate the issue. Defining international crimes remains a frustrating, often technical, exercise that shifts the focus to individual criminal responsibility rather than on saving lives. The Security Council's referral of the situation in Darfur to the ICC is not a victory but a sham - whatever satisfaction may be gained by ultimately holding President al-Bashir and others accountable for the atrocities they

25 This interpretation is accepted by the International Crisis Group, one of the most vocal supporters of R2P, in a report on the Russian-Georgian war over South Ossetia: "The 2005 GA Outcome Document makes it clear beyond argument that any country or group of countries seeking to apply forceful means to address an R2P situation, where another country is manifestly failing to protect its people and peaceful means are inadequate, must take that action through the Security Council . . . The Russia-Georgia case highlights the dangers and risks of states, whether individually or in a coalition, interpreting global norms unilaterally and launching military action without UN Security Council authorisation. The sense of moral outrage at reports of civilians being killed and ethnically cleansed can have the unintended effect of clouding judgment on the best response, which is another reason to channel action collectively through the United Nations. The Russian references to similar action by other P5 members in other theaters may reinforce doubts about those other instances but does not justify the Russian actions in Georgia. Indeed they reinforce the dangers of vigilante justice across borders." International Crisis Group, "The Georgia-Russia Crisis and the responsibility to protect”, available at www.crisisgroup.org/home/index.cfm?id=4521\&l=1\#situations.

26 Ibid.

27 A Guterres, "Millions uprooted: saving refugees and the displaced" (Sept/Oct 2008) 87 Foreign Affairs 90, at 93. The reluctance of developing and other countries to embrace the concept is detailed in C Focarelli, "The responsibility to protect doctrine and humanitarian intervention: too many ambiguities for a working doctrine" (2008) 13 Journal of Conflict and Security Law 191.

28 ICISS Report, para. 4.19. "Apprehended" is implicitly defined in the preceding paragraph as "imminently likely to occur”. Ibid. para. 4.18 . 
encouraged or condoned will be of little comfort to those who have died since the council's refusal to take meaningful action in 2003 and 2004. ${ }^{29}$

\section{Confusion with human rights}

As noted above, a state's responsibility to protect its population from harm extends far beyond the four crimes mentioned in the 2005 Summit Outcome, as recognised in the Secretary General's 2009 report on the responsibility to protect. ${ }^{30}$ However, the 2009 report curiously adds the phrase "and violations" to most mentions of the four crimes, apparently as a means of tying the 2005 Summit Outcome's version of the responsibility to protect against crimes to the broader responsibility of states to respect, ensure, and recognise international human rights. ${ }^{31}$

This newly coined phrase of "crimes and violations" provides a context for the broad discussion of human rights that makes up the bulk of the 2009 report, which is organised around the concept of three "pillars", that is the protection responsibilities of the state, international assistance and capacity-building, and timely and decisive response.

Discussion of the first pillar includes the observation that states "need to move from identity-based politics to the effective management, even encouragement, of diversity through the principle of non-discrimination and the equal enjoyment of rights". 32 This somehow should lead states to assist the UN Human Rights Council in "sharpening its focus" and to ratify relevant instruments on human rights, humanitarian law and refugees. ${ }^{33}$ Among other wide-ranging recommendations are preventing sexual and gender-based violence, ${ }^{34}$ ending impunity, ${ }^{35}$ "[c]andid self-reflection" and "searching dialogue", 36 training ${ }^{37}$ and fostering individual responsibility 38 - all to help prevent the mass atrocity crimes that fall within the responsibility to protect.

The second pillar, international assistance and capacity-building, is equally broad, ranging from "dialogue, education and training on human rights and humanitarian standards" 39 to addressing "development deficits" 40 to the preventive deployment of UN peacekeepers. ${ }^{41}$

29 The Security Council has referred to the responsibility to protect only twice since 2005, both times in the context of the protection of civilians in armed conflict. Res. 1674 (28 April 2006) "reaffirms" paras 138 and 139 of the World Summit Outcome Document, and Res. 1706 (31 August 2006), on the situation in Darfur, simply recalls Res. 1674, including that reaffirmation.

30 See Implementing the Responsibility to Protect, Report of the Secretary General, UN Doc. A/63/677 (2009) [2009 SG Report], para. 10(b): “The responsibility to protect applies . . . only to the four specified crimes ...”.

31 The phrase "crimes and violations" is repeated on numerous occasions in the report; see, ibid. paras 10(b), 10 (d), 17, 18, 19, 23, 29, 32, 35, 38, 43, 49, 50, 54, 56, 57, 58, 59, 60, 66 and Annex, paras 1, 4, 5 and 7.

32 Ibid. para. 14.

33 Ibid. paras 16, 17.

34 Ibid. para. 17.

35 Ibid. para. 19.

36 Ibid. para. 21.

37 Ibid. para. 25.

38 Ibid. para. 27.

39 Ibid. para. 33.

40 Ibid. para. 43.

41 Ibid. para. 41. The report refers to Macedonia, Burundi, Sierra Leone, and the Democratic Republic of the Congo as instances of successful deployments, although each pre-dated any UN reference to R2P; one wonders, then, what the added value of the term might be. Ibid. para. 42 . 
What is most needed, from the perspective of the responsibility to protect, are assistance programmes that are carefully targeted to build specific capacities within societies that would make them less likely to travel the path to crimes relating to the responsibility to protect. ${ }^{42}$

Unfortunately, as the report notes, we don't “understand fully what works where and why". 43

The third pillar, a timely and decisive response, encompasses the whole range of "tools" that the international community has developed over the years to assist in conflict management or resolution, such as on-site investigations, fact-finding, targeted sanctions, restricting arms flows, and the unspecified role of “individuals, advocacy groups, women's groups and the private sector". 44 States are encouraged to consider "the principles, rules and doctrine that should guide the application of coercive force in extreme situations", 45 as well as the possibility of developing a rapid-response military capacity, ${ }^{46}$ but there is no substantive discussion of these issues.

By intertwining post-2005 attempts to invigorate the responsibility to protect with decades-old attempts to hold countries accountable for human rights violations, the Secretary General does little more than repeat well trodden ground that diplomats and human rights activists have debated for years. By linking the unpopular concept of the responsibility to protect to the widely accepted concept of state responsibility for human rights (evidenced by the thousands of ratifications of human rights treaties), the Secretary General risks undermining the latter for no apparent reason. By promoting the idea that the responsibility to protect encompasses all that is good and desirable, the United Nations has embellished it with everything from human rights to humanitarianism, and it is difficult to imagine that the platitudes that infuse the 2009 report will be given content in some future iteration.

Implementing human rights is difficult enough without the baggage of the responsibility to protect, and joining the two concepts is unlikely to help either gain adherents.

\section{Kosovo}

Some advocates trace the origins of the responsibility to protect to the 1994 genocide in Rwanda, but its true genesis is in the illegal NATO bombing of Kosovo and Serbia in 1999. The International Commission on Intervention and State Sovereignty was created a year later, in 2000, and it reflected a desire to find legal cover, even if ex post facto, for a use of force that many in Europe and North America viewed as legitimate and even morally required. Unfortunately, the fact that most of the same NATO members who bombed Kosovo in 1999 have recognised the independence that Kosovo declared in 2008 confirms the worst fears of those who see theoretically "humanitarian" intervention as a first step to overthrowing governments and breaking up the territorial integrity and independence that many states won only a few decades ago.

The most serious problem with Kosovo as a model or excuse for the responsibility to protect is that the intervention itself fell well outside the parameters of the ICISS Report's subsequent formulation of "just cause", proportionality, and "right authority". The

42 Ibid.

43 Ibid.

44 Ibid. paras 49-59.

45 Ibid. para. 62.

46 Ibid. para. 64. 
Independent International Commission on Kosovo, hardly biased towards Serbia, concluded that the level of abuses in Kosovo prior to the commencement of the NATO bombing "were comparable with those of numerous other recent counter-insurgency wars, for example Colombia or Turkey". 47 The commission believed that the use of force was based not on an immediate threat but on "a weaving together of past experiences and future concerns". ${ }^{48}$ Is this what should trigger a bombing campaign?

Similarly, the OSCE, in a report on Kosovo released in December 1999, found arbitrary killings of non-combatants by both sides. It stated that the Racak massacre of 45 civilians in January 1999 was "indicative" of what was to follow after the bombing began, but the "more frequent occurrence in the period of the OSCE-KVM's presence in Kosovo [OSCE's monitoring mission, from October 1998 to June 1999] was, however, killings on an individual basis"; the report referred specifically to only 70 Serb and four UCK (the Albanian language acronym for the Kosovo Liberation Army, or KLA) killings from midOctober 1998 until the NATO bombing campaign began on 20 March 1999.49

There is no doubt that serious repression, human rights violations and international crimes were committed in Kosovo. However, if responsibility to protect advocates believe that Kosovo is a good example of the concept in action - and that the independence of Kosovo is to be welcomed - then they must be prepared to deal with perhaps several dozen similar situations around the world. The potential scope for intervention that this suggests is unlikely to persuade many countries to join the cause, even with the limiting language adopted in the 2005 Summit Outcome.

\section{Conclusion}

I am a human rights lawyer and professor, and I do not believe that sovereignty is sacrosanct. I support the proposition that intervention to prevent massive loss of life is morally justifiable and should be legal under international norms. I therefore am uncomfortable criticising a concept and campaign that could potentially save lives, if it were truly embraced by states.

However, by initially casting their nets too widely or vaguely in terms of the authority necessary to authorise intervention and the obligations imposed on the interveners, many responsibility to protect advocates risked alienating potential allies in both the north and south. The scope of intervention called for with regularity by organisations such as the International Crisis Group and others would lead to a situation that would resemble the neo-colonisation of much of Africa - even if this time it might be more honestly based on a humanitarian understanding of the "white man's burden" to protect Africans from themselves. While this is, of course, an overstatement, one need only imagine what Africa would look like if the "international community" did, in fact, intervene everywhere that intervention based on the responsibility to protect has been promoted by crisis-oriented NGOs.

Responsibility to protect advocates now emphasise the need for prevention, technical assistance, and capacity building in order to implement the concept, and such measures

47 Independent International Commission on Kosovo, Kosovo Report (Oxford: Oxford University Press, 2000), p. 136. The members of the commission were Richard Goldstone (co-chair), Carl Tham (co-chair), Grace d'Almeida, Hanan Ashwari, Akiko Domoto, Richard Falk, Oleg Grinevsky, Michael Ignatieff, Mary Kaldor, Martha Minow, Jacques Rupnik, Theo Sommer and Jan Urban.

48 Ibid. p. 159.

49 Organization for Security and Cooperation in Europe, Kosovo/Kosova, As Seen, As Told, available at www.osce.org/kosovo/documents/reports/hr/part1, ch. 5. 
must surely be welcomed. Unfortunately, repetition is not the same as innovation, and there is little in post-2005 discussions of the responsibility to protect that differs from earlier attempts to promote observance of the entire range of human rights responsibilities that states have accepted, as opposed to merely preventing a few serious international crimes.

Those who view the glass as half full interpret the 2005 Summit Outcome as a welcome acceptance by the General Assembly of the legitimacy of Security Council action to prevent international crimes, and there may be merit to this observation. In fact, however, the General Assembly simply declined to expand the available legal justifications for the use of force, and there is no doubt that many R2P advocates inside and outside of government continue to believe that intervention might be legitimate (moral? legal?) in emergencies, if the Security Council fails to act.

Using force to prevent or stop the widespread loss of life is the key issue, and throwing all that is "good" into the responsibility to protect distracts from realistic consideration of how intervention can be defined and accepted by the "international community", not just by Canada and its allies. Attempts to refocus the R2P debate on prevention and capacity building have added nothing to long-standing debates about how such proposals might be implemented. Substituting the responsibility to protect mantra for real debate over how to prevent and respond to mass atrocities will lead nowhere, and, in its present form, responsibility to protect proponents appear to be doing little more than trying to breathe life into a slogan. 
